\title{
Article \\ Cobalt Regulates Activation of Camk $2 \alpha$ in Neurons by Influencing Fructose 1,6-Bisphosphatase 2 Quaternary Structure and Subcellular Localization
}

\author{
Przemysław Duda *(D), Bartosz Budziak (D) and Dariusz Rakus *(D) \\ Department of Molecular Physiology and Neurobiology, University of Wrocław, 50-335 Wrocław, Poland; \\ bartosz.budziak@uwr.edu.pl \\ * Correspondence: przemyslaw.duda@uwr.edu.pl (P.D.); dariusz.rakus@uwr.edu.pl (D.R.)
}

check for

updates

Citation: Duda, P.; Budziak, B.;

Rakus, D. Cobalt Regulates

Activation of Camk $2 \alpha$ in Neurons by

Influencing Fructose 1,6-

Bisphosphatase 2 Quaternary

Structure and Subcellular

Localization. Int. J. Mol. Sci. 2021, 22,

4800. https://doi.org/10.3390/

ijms22094800

Academic Editor: Zoya Marinova

Received: 29 March 2021

Accepted: 29 April 2021

Published: 30 April 2021

Publisher's Note: MDPI stays neutral with regard to jurisdictional claims in published maps and institutional affiliations.

Copyright: (C) 2021 by the authors Licensee MDPI, Basel, Switzerland. This article is an open access article distributed under the terms and conditions of the Creative Commons Attribution (CC BY) license (https:/ / creativecommons.org/licenses/by/ $4.0 /)$.

\begin{abstract}
Fructose 1,6-bisphosphatase 2 (Fbp2) is a gluconeogenic enzyme and multifunctional protein modulating mitochondrial function and synaptic plasticity via protein-protein interactions. The ability of Fbp2 to bind to its cellular partners depends on a quaternary arrangement of the protein. $\mathrm{NAD}^{+}$and $\mathrm{AMP}$ stabilize an inactive T-state of Fbp2 and thus, affect these interactions. However, more subtle structural changes evoked by the binding of catalytic cations may also change the affinity of $\mathrm{Fbp} 2$ to its cellular partners. In this report, we demonstrate that Fbp2 interacts with $\mathrm{Co}^{2+}$, a cation which in excessive concentrations, causes pathologies of the central nervous system and which has been shown to provoke the octal-like events in hippocampal slices. We describe for the first time the kinetics of $\mathrm{Fbp} 2$ in the presence of $\mathrm{Co}^{2+}$, and we provide a line of evidence that $\mathrm{Co}^{2+}$ blocks the AMP-induced transition of Fbp2 to the canonical T-state triggering instead of a new, non-canonical T-state. In such a state, $\mathrm{Fbp} 2$ is still partially active and may interact with its binding partners e.g., $\mathrm{Ca}^{2+} /$ calmodulin-dependent protein kinase $2 \alpha$ (Camk $\left.2 \alpha\right)$. The Fbp2-Camk2 $\alpha$ complex seems to be restricted to mitochondria membrane and it facilitates the Camk $2 \alpha$ autoactivation and thus, synaptic plasticity.
\end{abstract}

Keywords: Fbp2; mitochondria; protein-protein interaction; moonlighting protein

\section{Introduction}

Fructose 1,6-bisphosphatase $(\mathrm{Fbp})$ is a regulatory enzyme of gluco- and glyconeogenesis which hydrolyses fructose-1,6-bisphosphate to fructose-6-phosphate and inorganic phosphate. The liver Fbp (Fbp1) is expressed mainly in gluconeogenic tissues and organs such as the liver, kidney, and jejunum, while the muscle Fbp (Fbp2) is the sole Fbp in striated muscles and it is ubiquitously expressed in all non-gluconeogenic tissues [1]. Fbp2 is also the predominant form of the enzyme in neurons [2]. Aside from regulation of glycogen synthesis from carbohydrate precursors, $\mathrm{Fbp} 2$, as a moonlighting protein, is engaged in cell cycle-dependent events [1], activation of synaptic plasticity phenomena [2], and regulation of activity of transcriptional factors [3-6]. It has been demonstrated that Fbp2 protects mitochondria against stress conditions such as a high level of calcium and its consequences (mitochondrial swelling and decreased ATP synthesis) [2,7]. In solution, Fbp2 exists as a mixture of various oligomeric forms, mainly dimers and tetramers [8,9]. The protein oligomerization is regulated by its allosteric effectors (AMP and NAD ${ }^{+}$) which stabilize an inactive tetrameric T-state $[8,10]$ while in the absence of the allosteric inhibitors, Fbp2 may exist both as a dimer and an active tetrameric R-state protein [8]. In the active R-state ("relaxed state"), Fbp2 adopts a cross-like quaternary arrangement of its subunits, in which the upper dimer is rotated by nearly $90^{\circ}$ with respect to the lower dimer while in the T-state ("tense state"), both dimers form practically planar tetramer [9]. In contrast to the T-state, Fbp2 dimers and, presumably, R-state tetramers can associate with mitochondria [8,11].

Fbp2 may be translocated to the cell nucleus in a hormone-dependent manner [12] where it regulates transcriptional activities of c-Myc and Hif1 $\alpha$ [3-6]. Recently, Fbp2 has 
been shown to regulate synaptic plasticity by influencing the induction and maintenance of early and late phases of long-term potentiation (LTP). In its active form, Fbp2 stimulates the autoactivation of an early LTP effector kinase $\left(\mathrm{Ca}^{2+} /\right.$ calmodulin-dependent protein kinase 2, Camk2) and the expression of a late LTP-related transcription factor (c-Fos). Silencing of Fbp2 expression or pharmacological inhibition/tetramerization of the protein abolishes the hallmarks of LTP induction [2].

For catalysis, Fbp2 requires divalent cations as $\mathrm{Mg}^{2+}, \mathrm{Mn}^{2+}$ or $\mathrm{Zn}^{2+}$ while $\mathrm{Ca}^{2+}$ inhibits the isozyme [13]. Interestingly, it has been also shown that Fbp1 can interact with cobalt ions which inhibit the catalysis [14].

Cobalt is a microelement essential for mammals as a constituent of vitamin $B_{12}$ (cobalamin) which acts as a coenzyme for isomerases and methyltransferases. The vitamin participates for example in the methylmalonyl-CoA mutase reaction, in which some amino acids are catabolized into succinyl-CoA [15], and in the methionine synthase reaction, in which methionine and tetrahydrofolate are generated [16]. The former reaction is necessary for proper myelin synthesis [17] and the latter is indispensable for DNA synthesis (low tetrahydrofolate level results in ineffective cell production with rapid turnover, like in the megaloblastic anemia) [16]. Physiological $\mathrm{Co}^{2+}$ and vitamin $\mathrm{B}_{12}$ plasmatic concentrations are $<0.2 \mathrm{ng} / \mathrm{mL}$ and $200-900 \mathrm{pg} / \mathrm{mL}$, respectively, whereas the Co dietary intake varies from 5 to $50 \mu \mathrm{g}$ per day [18].

On the other hand, excessive Co exposure results in the development of pathologies of the respiratory system, heart, thyroid, and central nervous system. This exposure may be a result of air pollution, occupational exposure, and the release of Co ions from implanted prostheses materials [18]. Moreover, $\mathrm{Co}^{2+}$ can replace $\mathrm{Zn}^{2+}$ in alkaline phosphatase what makes the enzyme much less active [19] and thus, inhibits osteoblasts activity. This reduces calcium deposition in bones and tips the balance towards osteolysis [20].

Neurotoxicity of $\mathrm{Co}^{2+}$ is well documented and manifests itself in deafness, tinnitus, peripheral neuritis, paresthesia, unsteady gait, and optic atrophy [21,22]. Additionally, direct intracranial $\mathrm{Co}^{2+}$ application induces seizures in mice, rats, cats, and monkeys [23-26]. It has been shown that Co-induced seizures have common features with human epilepsies regarding the intermittent occurrence, paroxysmal nature, and response to anticonvulsants [27]. Moreover, it has been demonstrated, using murine hippocampal slices, that the ictal-like discharges originated from the $\mathrm{CA} 3$ area are not associated with impaired GABAergic inhibition in the CA3 circuit [28], and thus, it may be presumed that they are related to increased glutamate-dependent excitatory transmission.

Because $\mathrm{Fbp} 2$ is involved in glutamate-dependent transmission and $\mathrm{Fbp} 1$ can bind $\mathrm{Co}^{2+}$ which in turn is known to cause epileptic-like events, we decided to investigate whether the effect of the cation in the brain could be mediated by Fbp2. In this paper, we present the kinetic and structural properties of Fbp2 in the presence of $\mathrm{Co}^{2+}$, and we demonstrate the effects of this cation on Fbp2 subcellular localization and its moonlighting activities in neurons.

\section{Results and Discussion}

\subsection{The Effect of Cobalt Ions on Fpb2 Kinetics, Structure and Subcellular Localization}

$\mathrm{Fbp} 2$ is a moonlighting protein that can be engaged in many cellular processes depending on its subcellular localization [1] which in turn, is regulated by the oligomeric and conformational state of the protein. The dimeric and tetrameric R-state Fbp2 can associate with mitochondria $[8,11]$, whereas only the tetrameric form can be retained in the cell nucleus [8]. To explore if $\mathrm{Co}^{2+}$ influences the subcellular localization of Fbp2 we checked the $\mathrm{Fbp}$-mitochondria colocalization and the nuclear accumulation of the protein after incubation of neuronal cultures with $\mathrm{CoCl}_{2}$ for $24 \mathrm{~h}$ (Figure 1a,b). 
A Mitochondria/Fbp
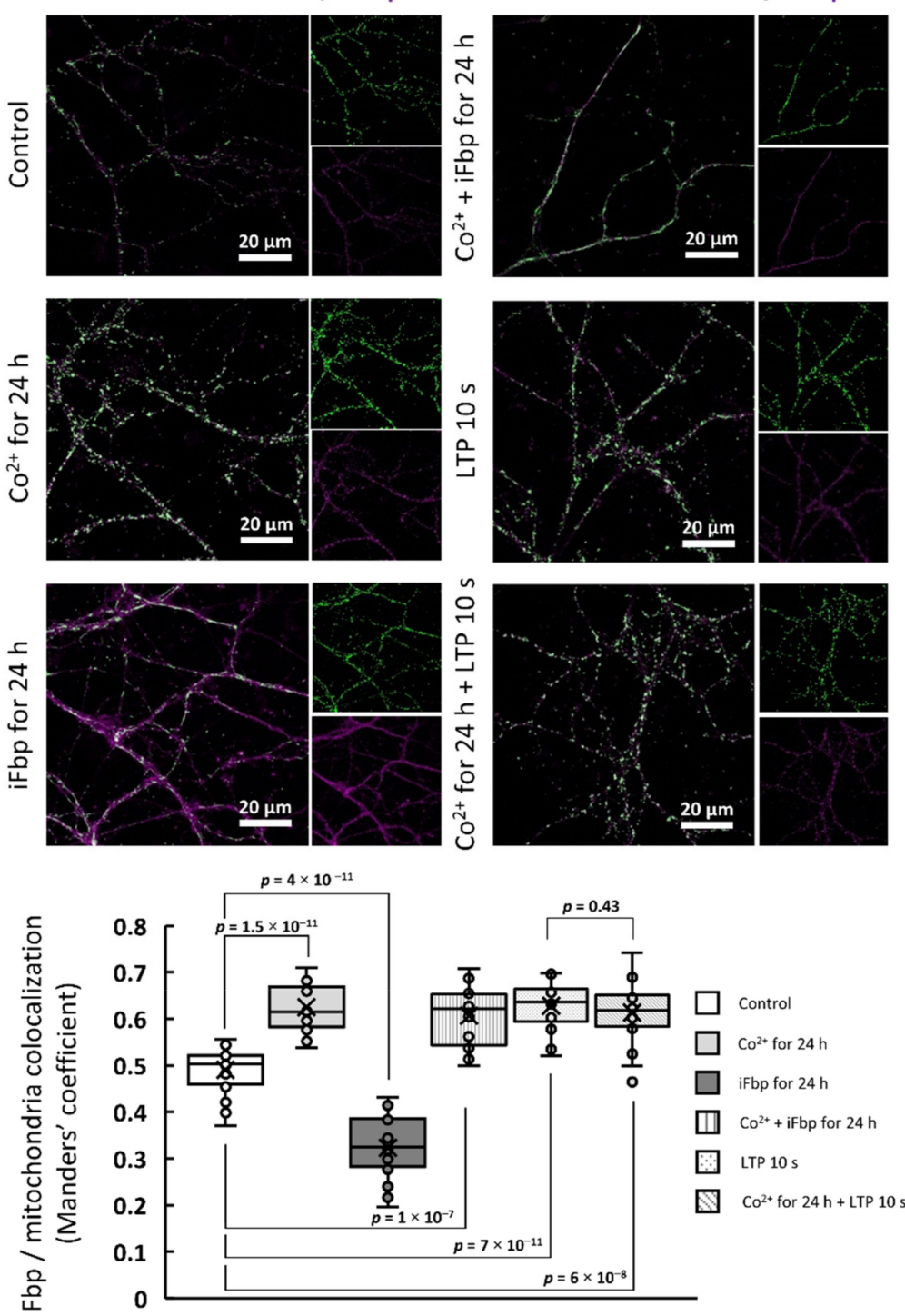

B
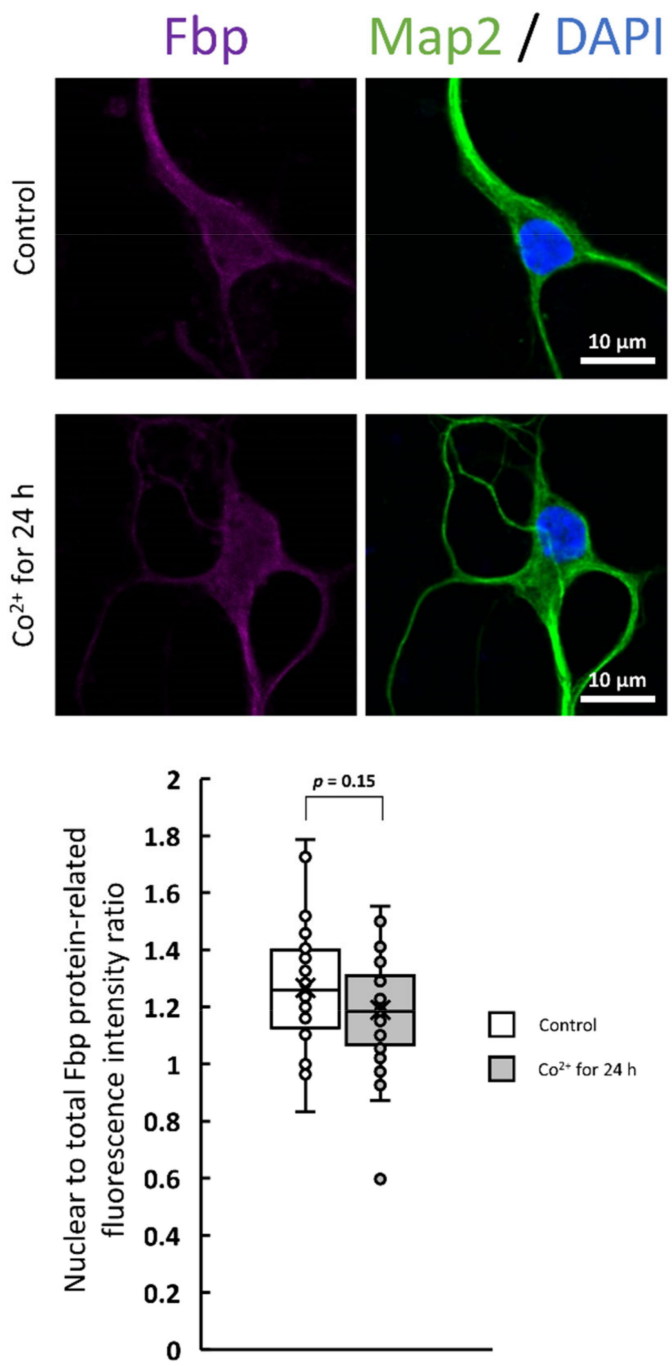

Figure 1. $\mathrm{Co}^{2+}$ stimulates $\mathrm{Fbp} 2$ association with mitochondria but it does not alter the nuclear accumulation of the protein. (A) Fbp-mitochondria colocalization is significantly increased in $\mathrm{Co}^{2+}$-treated neurons both in the presence and in the absence of $\mathrm{Fbp}$ inhibitor (iFbp). In the presence of $\mathrm{Co}^{2+}$, the amount of mitochondria-bound Fbp is as high as after the LTP induction. The iFbp-treated neurons show reduced colocalization compared to control cells. (B) $\mathrm{Co}^{2+}$ treatment does not change the nuclear accumulation of Fbp in neurons.

This treatment significantly increased the Fbp-mitochondria colocalization quantified as Manders' colocalization coefficient $(\mathrm{M})$ with a value of $0.63 \pm 0.05$ after $^{\mathrm{Co}^{2+}}$ treatment, $^{2}$ and $0.49 \pm 0.05$ in the absence of $\mathrm{Co}^{2+}$ (Figure 1a). This suggested that $\mathrm{Co}^{2+}$ modified the conformation and/or oligomeric state of the enzyme. However, quite unexpectedly, the presence of $\mathrm{Co}^{2+}$ did not alter the nuclear amount of the protein expressed as the ratio of Fbp2-related fluorescence from the nuclear area to the total Fbp2-related fluorescence from a cell (Figure 1b).

Our previous study has demonstrated that the AMP-driven transition of Fbp2 quaternary structure from the R- to T-state precludes its interaction with mitochondria [11]. Thus, to clarify the impact of $\mathrm{Co}^{2+}$ on the Fbp2 protein structure we tested if $\mathrm{Co}^{2+}$ can prevent the protein dissociation from mitochondria induced by the $\mathrm{Fbp}$ inhibitor (iFbp) which mimics the action of AMP on the enzyme conformation [29,30]. 
In line with our previous studies [2], we observed that the incubation of neurons with iFbp decreased colocalization of Fbp with mitochondria ( $M=0.32 \pm 0.07$; Figure 1a). However, when the incubation with iFbp was carried out in the presence of $\mathrm{Co}^{2+}$, the effect of the inhibitor was abolished $(\mathrm{M}=0.60 \pm 0.06$; Figure 1a).

The association of Fbp2 with mitochondria is indispensable for induction and maintenance of the LTP [2], a molecular basis for memory formation and learning. Here, we found that $\mathrm{Co}^{2+}$ did not influence the LTP-induced Fbp-mitochondria colocalization: after the induction, the $\mathrm{M}$ values were similar in neurons untreated $(0.63 \pm 0.05)$ and treated $(0.61 \pm 0.07)$ with $\mathrm{Co}^{2+}$ (Figure 1a).

To further clarify the influence of cobalt on the conformation and/or the oligomeric state of Fbp2, we used the size-exclusion chromatography (SEC) and Native-PAGE. The SEC analysis revealed that $\mathrm{Co}^{2+}$ could not induce dissociation of $\mathrm{Fbp} 2$ tetramers into dimers (Figure 2a). This was corroborated by results of the Native-PAGE experiments which showed that $\mathrm{Co}^{2+}$ had no effect on Fbp2 mobility and thus, it presumably did not affect the structure of the enzyme. Evidently, in the presence of $\mathrm{Co}^{2+} \mathrm{Fbp} 2$ adopted an R-like tetrameric structure (Figure $2 b$ ).

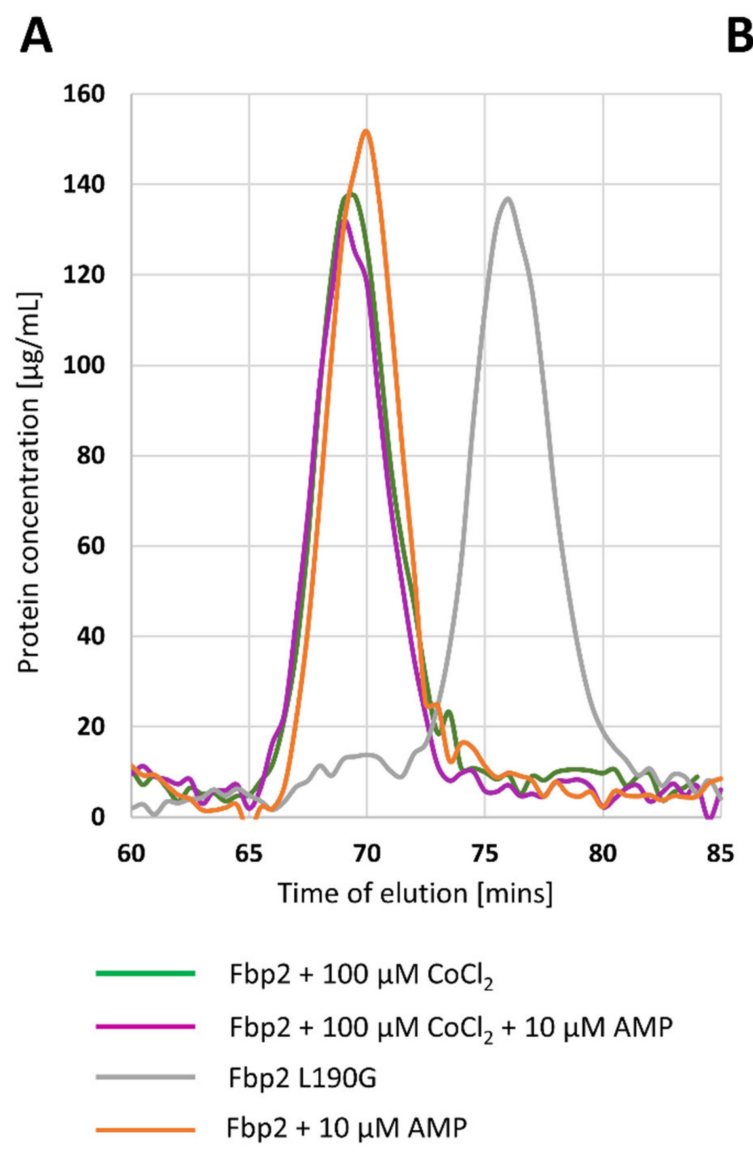

B
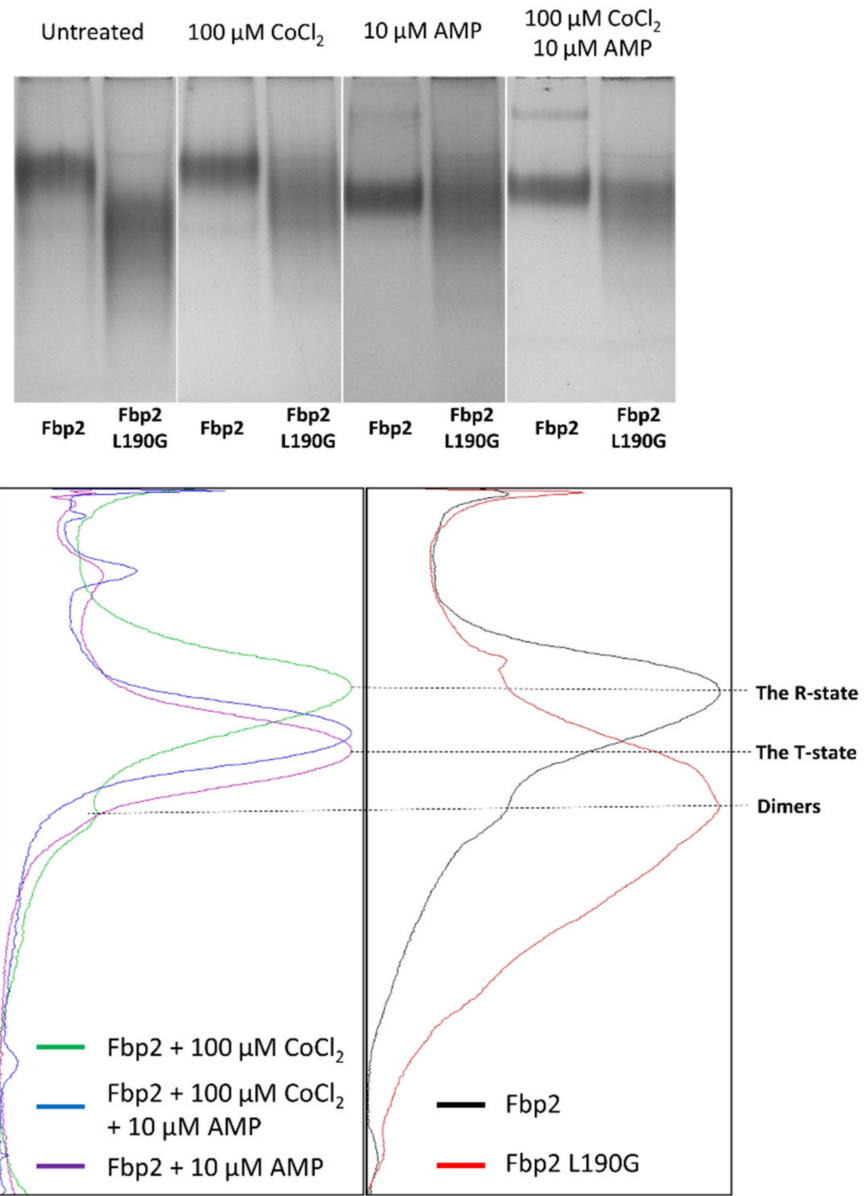

Figure 2. $\mathrm{Co}^{2+}$ does not modulate oligomerization of Fbp2 but it affects the AMP-bound protein migration in the NativePAGE. (A) Size-exclusion chromatography (SEC) reveals that in a presence of AMP and $\mathrm{Co}^{2+}$, Fbp2 adopts tetrameric conformation. As a control, we used the Fbp2 L190G mutein which cannot tetramerize and adopts dimeric form only. (B) Migration of the $\mathrm{Co}^{2+}$-saturated and $\mathrm{Co}^{2+}$-free $\mathrm{Fbp} 2$ in the Native-PAGE is similar. In the absence of ligands, Fbp2 migrates mainly as the R-state tetramers, although the small amount of dimers is also visible (black line). The dimeric arrangement is the only confirmation for the Fbp2 L190G mutein (red line). The mobility of the AMP-induced T-state $\mathrm{Fbp} 2$ (magenta line) is increased as compared to the R-state. However, in the simultaneous presence of $\mathrm{Co}^{2+}$ and $\mathrm{AMP}$, the mobility of Fbp2 (blue line) does not fully reflect that observed in the presence of AMP alone. 
It may be also concluded that in the presence of the cation, the dimers-tetramers ratio within the cell remained unchanged too. This would explain the lack of changes in nuclear localization of $\mathrm{Fbp} 2$ in neurons treated with $\mathrm{Co}^{2+}$. The nuclear export sequence is located on the interface of Fbp2 dimers, which makes it inaccessible to export machinery when the enzyme forms tetrameric R- and T-state structures [8].

The addition of AMP to the running buffer stimulates transition of Fbp2 from the Rto T-state and both states migrate with significantly different velocities in the Native-PAGE because, in the R-state, Fbp2 adopts a cruciform-like arrangement of subunits while the T-state is practically flat and thus, various charged residues are exposed on the surface of the protein. Interestingly, we found that $\mathrm{Co}^{2+}$ affected migration of the AMP-saturated $\mathrm{Fbp} 2$. We observed a slightly slower migration of Fbp2 in the presence of $\mathrm{Co}^{2+}$ and AMP than in the presence of AMP alone (Figure $2 b$ ). This suggested that in the presence of $\mathrm{Co}^{2+}$ and $\mathrm{AMP}, \mathrm{Fbp} 2$ adopted the T-like quaternary arrangement which was, however, different from the canonical T-state. In this new T-like state Fbp2 is apparently still able to associate with mitochondria.

Immunofluorescent studies revealed that the Fbp-related signal was significantly higher in neurons treated with $\mathrm{Co}^{2+}$ than in control cells, while it was reduced in neurons incubated with the allosteric inhibitor iFbp (Figure 3a). However, the effect of iFbp was abolished in the presence of $\mathrm{Co}^{2+}$ (Figure $3 \mathrm{a}$ ). On the other hand, Western blot (WB) analysis did not show significant differences in the level of the Fbp protein under almost any of these conditions (Figure 3b). The only change we observed was the decrease of the Fbp2 protein in the extract obtained from neurons incubated with iFbp (Figure 3b), in line with the results of the immunofluorescent study (Figure 3a). This suggested that induction of the canonical T-state by iFbp somehow directed Fbp2 to degradation but simultaneous incubation with $\mathrm{Co}^{2+}$ prevented this modification and thus, degradation of the protein (Figure 3b).
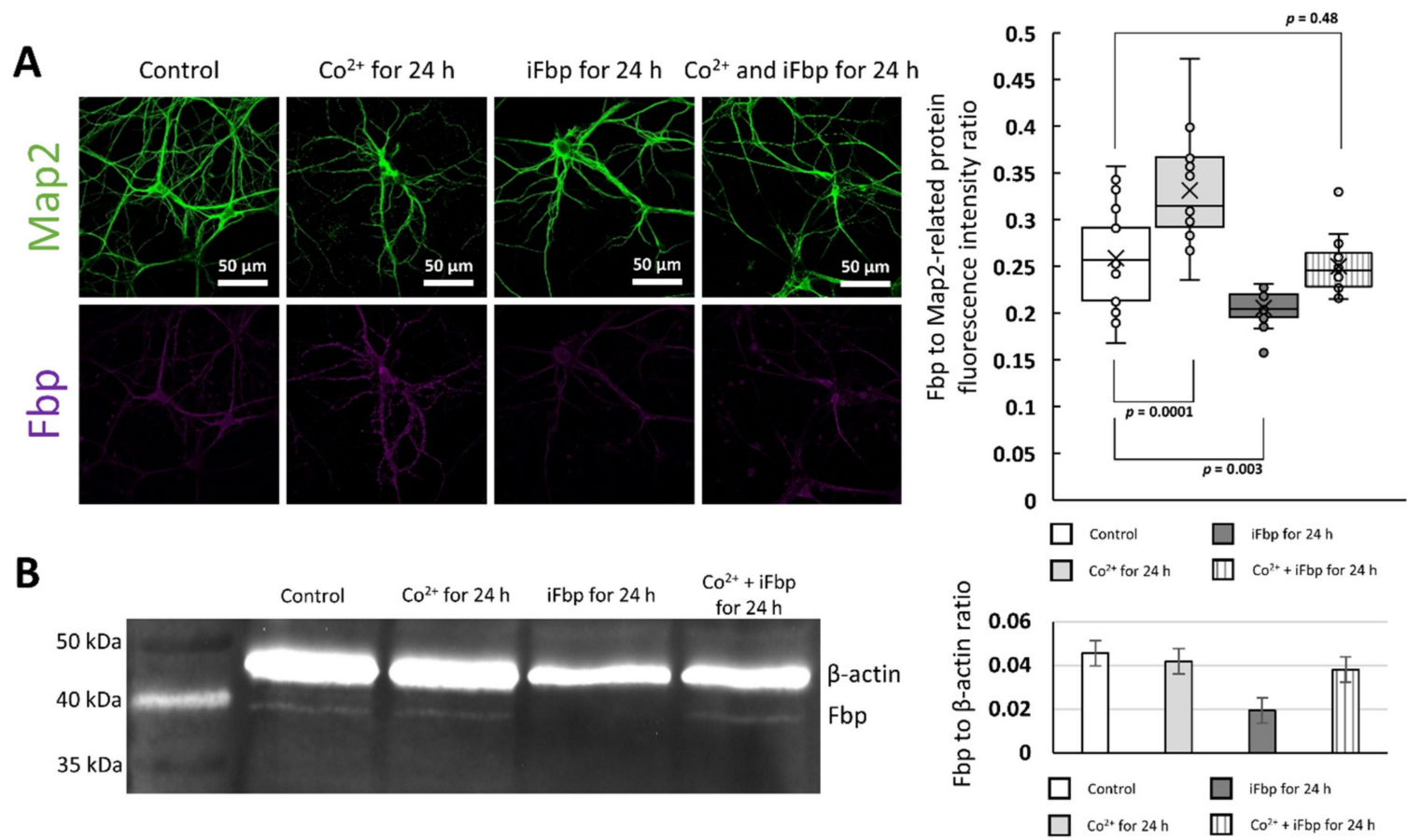

Figure 3. Quantification of Fbp2 protein in $\mathrm{Co}^{2+}$-treated neurons. (A) Fbp-related fluorescent signal in neurons incubated with $\mathrm{Co}^{2+}$ is significantly higher than in control cells, whereas the fluorescence is lower in iFbp-treated cells. The decrease in Fbp fluorescence is not observed in neurons treated simultaneously with iFbp and $\mathrm{Co}^{2+}$. (B) Western blot analysis demonstrates that $\mathrm{Fbp} 2$ protein amount does not differ significantly among control neurons, neurons incubated with $\mathrm{Co}^{2+}$, and with $\mathrm{Co}^{2+} / \mathrm{iFbp}$ mixture. Tetramerization of $\mathrm{Fbp} 2$ with iFbp reduces the protein-associated signal in comparison to control neurons. 
The observed inconsistency in the results of the immunofluorescence study (the increase of Fbp-related signal) and WB (the lack of increase in Fbp2 protein amount) after $\mathrm{Co}^{2+}$ treatment may have resulted from different availability of $\mathrm{Fbp} 2$ epitopes for the polyclonal antibodies in the immunofluorescent experiment. The T-state Fbp2 is an almost flat structure, whereas, in the R-state, the upper and the bottom dimers are oriented perpendicularly to each other (with the $\kappa$ angle value of $-85^{\circ}$ ) [9]. Thus, the molecular surface available for antibodies (and also for Fbp2 binding partners) in the R-state is much larger [9]. Therefore, the increased Fbp2-related fluorescence after $\mathrm{Co}^{2+}$ treatment together with the lack of the $\mathrm{Co}^{2+}$-induced changes in the protein amount in WB (Figure 3a,b) might suggest that the T-like quaternary arrangement induced by the cation is more similar to the $\mathrm{R}$ - than T-state and exposes more epitopes on its surface.

Since $\mathrm{Co}^{2+}$ protected $\mathrm{Fbp} 2$ from the action of iFbp in a cell and prevented stabilization of the canonical T-state, we decided to describe the kinetic properties of the enzyme in the presence of $\mathrm{Co}^{2+}$. To the best of our knowledge, this is the first report on the effect of $\mathrm{Co}^{2+}$ on Fbp2 kinetics. We have found that in the presence of an optimal concentration of $\mathrm{Mg}^{2+}$ (a catalytic cation; $1 \mathrm{mM}$ ), $\mathrm{Co}^{2+}$ inhibited the activity of $\mathrm{Fbp} 2$ in a cooperative manner with the $\mathrm{IC}_{50}$ value of $6.1 \mu \mathrm{M}$ (the Hill coefficient value was 1.41), and the maximal inhibition reaching about 79\% (Figure 4a). However, in the absence of $\mathrm{Mg}^{2+}, \mathrm{Co}^{2+}$ acted as a cooperative activator with the $\mathrm{AC}_{50}$ value of $8.6 \mu \mathrm{M}$ (the Hill coefficient value 2.00). The maximal activity observed in the presence of $\mathrm{Co}^{2+}$ was, however, significantly lower than that observed in the presence of $\mathrm{Mg}^{2+}$ (Figure $4 \mathrm{~b}$ ). Because the $\mathrm{IC}_{50}$ and $\mathrm{AC}_{50}$ values for the inhibition and activation by $\mathrm{Co}^{2+}$ were quite similar, it might be hypothesized that $\mathrm{Co}^{2+}$ was not an Fbp2 inhibitor but a catalytic cation that competed with $\mathrm{Mg}^{2+}$ for binding to the active site. However, since it supported the catalysis less efficiently than $\mathrm{Mg}^{2+}$ the specific activity of Fbp2 was lower.

We also compared the effect of various concentrations of $\mathrm{Co}^{2+}$ on the activity of $\mathrm{Fbp} 2$ in the presence of different $\left[\mathrm{Mg}^{2+}\right]$, and we observed that for all studied $\mathrm{Mg}^{2+}$ concentrations, increasing $\left[\mathrm{Co}^{2+}\right]$ led to the same $\mathrm{Fbp} 2$ activity which was equal to about $20 \%$ of the maximal activity observed in the presence of saturating $\mathrm{Mg}^{2+}$ concentration (Figure 4c). In all the cases, the titer of $\mathrm{Co}^{2+}$ required for the achievement of the maximal $\mathrm{Fbp} 2$ activity was about $30 \mu \mathrm{M}$ (Figure 4c). This reflected the cation concentration which saturated Fbp2 in the absence of $\mathrm{Mg}^{2+}$ (Figure $4 \mathrm{~b}$ ).

Similar phenomena have been observed in studies of the effect of $\mathrm{Zn}^{2+}$ on kinetic parameters of the liver Fbp. Crystallographic studies revealed that a single liver Fbp subunit binds three $\mathrm{Zn}^{2+}$ ions $[31,32]$ while only two $\mathrm{Mg}^{2+}$ associates with the subunit and the mechanism of the $\mathrm{Zn}^{2+}$ action relies on the competition with $\mathrm{Mg}^{2+}$ [33]. $\mathrm{Co}^{2+}$ and $\mathrm{Zn}^{2+}$ have similar radii, 74.5 and $74 \mathrm{pm}$, respectively, which suggests that the mode of inhibition/activation of $\mathrm{Fbp} 2$ by $\mathrm{Co}^{2+}$ may be similar as in the case of inhibition/activation of the liver $\mathrm{Fbp}$ by $\mathrm{Zn}^{2+}$. However, it has been shown that $\mathrm{Co}^{2+}$ prefers octahedral coordination while $\mathrm{Zn}^{2+}$ preference for tetrahedral coordination is the highest [34]. On the other hand, several studies have demonstrated that $\mathrm{Co}^{2+}$ could replace $\mathrm{Zn}^{2+}$ in the metal-binding sites although its association with the enzyme was weaker than in the case of $\mathrm{Zn}^{2+}[35,36]$. Our study showing that both the inhibition (in the presence of $\mathrm{Mg}^{2+}$ ) and the activation (in the absence of $\mathrm{Mg}^{2+}$ ) of Fbp2 by $\mathrm{Co}^{2+}$ are weaker than those caused by $\mathrm{Zn}^{2+}$ [14] corroborates the above-mentioned finding.

Next, we tested the effect of $\mathrm{Co}^{2+}$ on Fbp2 inhibition by AMP whose action is associated both with the stabilization of the tetrameric arrangement of Fbp2 and with the transition to the T-state [9]. We found that $\mathrm{Co}^{2+}$ significantly desensitized Fbp2 to AMP. In the presence of $1 \mathrm{mM} \mathrm{Mg}^{2+}, 10 \mu \mathrm{M}$ AMP inhibited Fbp2 in about $97 \%$ (Figure $4 \mathrm{~d}$ ). However, simultaneous incubation of the enzyme with $\mathrm{Mg}^{2+}$, AMP, and $100 \mu \mathrm{M} \mathrm{Co}^{2+}$ elevated the activity up to about $11 \%$ (Figure 4d). Similarly, the activity of Fbp2 in the absence of $\mathrm{Mg}^{2+}$ but in the presence of $10 \mu \mathrm{M}$ AMP and $100 \mu \mathrm{M}, \mathrm{Co}^{2+}$ was about $9 \%$ of the activity measured in the presence of $\mathrm{Mg}^{2+}$-saturating concentration (Figure 4d). Although the maximal activity of $\mathrm{Fbp} 2$ in the presence of $\mathrm{Co}^{2+}$ was lower than in the presence of 
$\mathrm{Mg}^{2+}$, the much weaker inhibition by AMP suggested that $\mathrm{Co}^{2+}$ associated with $\mathrm{Fbp} 2$ in a manner similar but not the same as $\mathrm{Mg}^{2+}$ did. Moreover, taking into account that mobility of $\mathrm{Co}^{2+}$ - and AMP-saturated $\mathrm{Fbp} 2$ varied from the mobility of the canonical T- and R-states one might assume that $\mathrm{Co}^{2+}$ association with $\mathrm{Fbp} 2$ led to exposition/disappearance of new, charged amino acid residues on the surface of the protein.

A

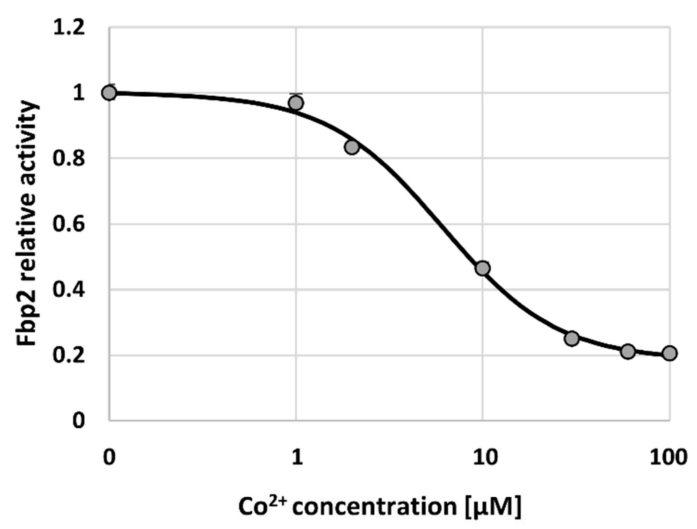

C 25

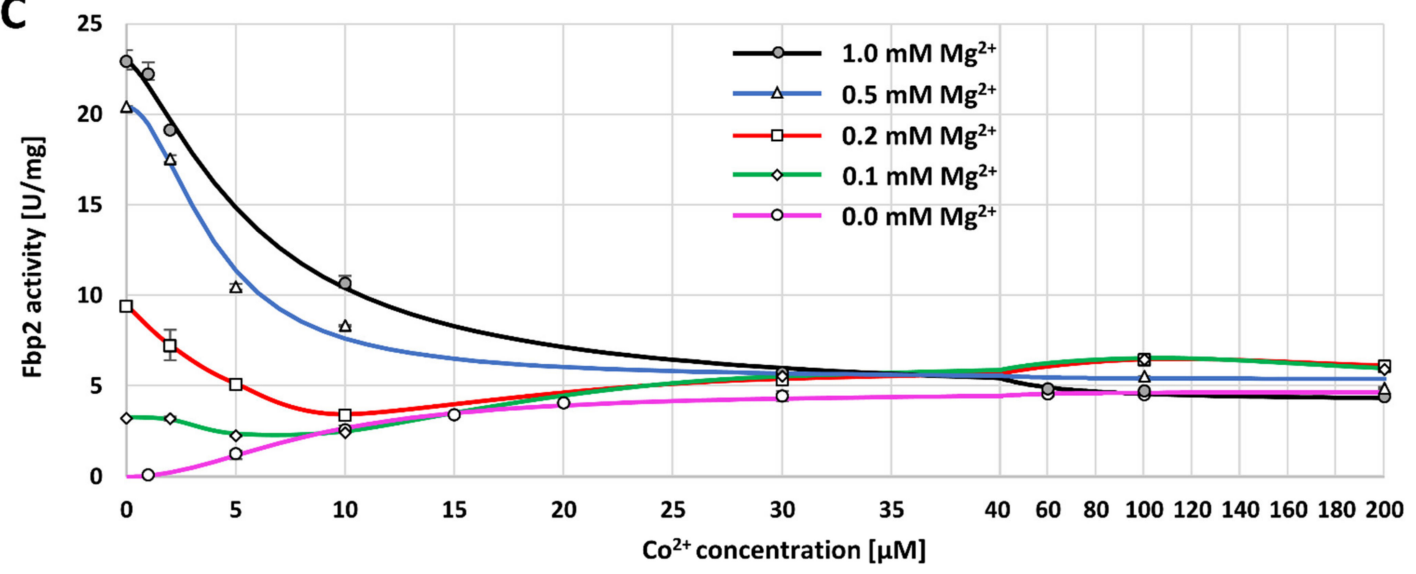

D

\begin{tabular}{|c|c|c|c|c|c|c|}
\hline Condition & $1 \mathrm{mM} \mathrm{Mg}^{2+}$ & $100 \mu \mathrm{M} \mathrm{Co}^{2+}$ & $\begin{array}{c}1 \mathrm{mM} \mathrm{Mg}^{2+} \\
100 \mu \mathrm{M} \mathrm{Co}^{2+}\end{array}$ & $\begin{array}{l}1 \mathrm{mM} \mathrm{Mg}^{2+} \\
10 \mu \mathrm{M} \text { AMP }\end{array}$ & $\begin{array}{c}1 \mathrm{mM} \mathrm{Mg}^{2+} \\
100 \mu \mathrm{M} \mathrm{Co}^{2+} \\
10 \mu \mathrm{M} \text { AMP }\end{array}$ & $\begin{array}{l}100 \mu \mathrm{M} \mathrm{Co}{ }^{2+} \\
10 \mu \mathrm{M} \text { AMP }\end{array}$ \\
\hline $\begin{array}{l}\text { Activity } \\
{[\mathrm{U} / \mathrm{mg}]}\end{array}$ & $22.9 \pm 0.4$ & $4.5 \pm 0.1$ & $4.8 \pm 0.1$ & $0.7 \pm 0.1$ & $2.4 \pm 0.3$ & $2.0 \pm 0.1$ \\
\hline $\begin{array}{l}\text { Activity } \\
\text { relative to } \\
1 \mathrm{mM} \mathrm{Mg}^{2+}\end{array}$ & $100 \%$ & $20 \%$ & $21 \%$ & $3 \%$ & $11 \%$ & $9 \%$ \\
\hline $\begin{array}{l}\text { Activity } \\
\text { relative to } \\
100 \mu \mathrm{M} \mathrm{Co}^{2+}\end{array}$ & $506 \%$ & $100 \%$ & $107 \%$ & $15 \%$ & $54 \%$ & $44 \%$ \\
\hline
\end{tabular}

Figure 4. The effect of $\mathrm{Co}^{2+}$ on Fbp2 kinetics. (A) $\mathrm{Co}^{2+}$ acts as an Fbp2 inhibitor in the presence of catalytic ions $\left(\mathrm{Mg}^{2+}\right)$ with the maximal inhibition of about $79 \%$ and $\mathrm{IC}_{50}$ value $6.1 \mu \mathrm{M}$, whereas $(\mathbf{B})$ in the absence of $\mathrm{Mg}^{2+}, \mathrm{Co}^{2+}$ activates Fbp2 with the $\mathrm{AC}_{50}$ value of $8.6 \mu \mathrm{M}$. (C) $\mathrm{Co}^{2+}$ acts in a cooperative manner competing with $\mathrm{Mg}^{2+}$ for binding to the active site of Fbp2. (D) Comparison of the Fbp2 enzymatic activity in the presence of $\mathrm{Co}^{2+}$, $\mathrm{AMP}$, and both the agents.

2.2. The Cobalt-Induced Fbp2 Mitochondrial Localization Enhances the Camk2 $\alpha$ Autoactivation in Hippocampal Neurons

Neurotoxicity of $\mathrm{Co}^{2+}$ is well documented [21,22]. It has been demonstrated that in mice hippocampal slices, $\mathrm{Co}^{2+}$-induced ictal-like discharges originate from the CA3 area 
and that their generation is not associated with impairment in GABAergic inhibition [28]. These epileptiform discharges are dependent on the activity of $\alpha$-amino-3-hydroxy-5methyl-4-isoxazolepropionic acid receptors (AMPARs) and overexpression of AMPAR in the brain has often been reported or suggested in various types of epilepsy [37]. Accumulation of AMPARs at synapses is essential for excitatory synaptic transmission, and targeting of AMPARs to synapses is mediated by the activity of Camk2 [38]. Moreover, a single AMPAR channel conductance increases due to receptor phosphorylation by Camk2 $[39,40]$. Previously, we have demonstrated that the activating autophosphorylation of Camk2 $\alpha$ is directly associated with the Fbp2 oligomerization state during the induction of LTP [2], which makes $\mathrm{Fbp} 2$ a good candidate for $\mathrm{Co}^{2+}$-mediated changes in neurotransmission.

Since $\mathrm{Co}^{2+}$ induced mitochondrial accumulation of Fbp2 thus, we investigated if this action could also influence Camk2 autoactivation. We found that $24 \mathrm{~h}$ incubation of neuronal cultures with $\mathrm{CoCl}_{2}$ significantly increased fluorescence related to antibodies directed to autophosphorylated Camk2 $\alpha$ (phosphorylated at Thr286) as compared to untreated neurons (Figure 5a). In contrast to $\mathrm{Co}^{2+}, \mathrm{iFbp}$ did not have any effect on the autophosphorylation. When neuronal cultures were treated simultaneously with $\mathrm{Co}^{2+}$ and iFbp, the autophosphorylation-related signal was similar to cells incubated with $\mathrm{Co}^{2+}$ only (Figure 5a). Additionally, we examined the fluorescent signal associated with the total amount of Camk $2 \alpha$ and we found that in the tested conditions, the profile of changes was similar to that seen for the autophosphorylated kinase (Figure $5 b$ ).

The above results suggested that $\mathrm{Co}^{2+}$ elevated the amount of activated Camk $2 \alpha$ and the total kinase level (Figure $5 a, b)$. To verify this we performed WB. As one could expect, the use of anti-Camk $2 \alpha$ antibodies resulted in two separate bands on the blotting membrane (Figure 5c). Because phosphorylated forms of proteins migrate slower in SDSPAGE [41] we attributed the lower Camk2 $\alpha$ band to the dephosphorylated and the upper band to the phosphorylated form of the kinase. The densitometric analysis revealed that the incubation of neurons with $\mathrm{CoCl}_{2}$ significantly elevated the total amount of Camk2 $\alpha$ in comparison to untreated neurons (Figure 5d). Moreover, $\mathrm{Co}^{2+}$ treatment significantly increased the ratio of the phosphorylated form of the kinase to its dephosphorylated form. Interestingly, the amount of Camk $2 \alpha$ remained unchanged after incubation of neurons with iFbp (Figure 5d).

Although the results of WB analysis confirmed the results of the immunofluorescence study in the part related to the $\mathrm{Co}^{2+}$ effects on Camk $2 \alpha$ (Figure $5 \mathrm{c}, \mathrm{d}$ ), using WB we observed neither a decrease in the total amount of Camk $2 \alpha$ protein after incubation of neurons with iFbp (Figure $5 c, d$ ) nor an elevation of Camk $2 \alpha$ forms after simultaneous treatment with $\mathrm{Co}^{2+}$ and iFbp (Figure $5 c, d$ ). This discrepancy may be related to the specificity of the antibodies used in the study, which were synthesized toward the carboxyterminal Camk $2 \alpha$ residues (residues 461-478). These residues are tightly packed in the center of the Camk2 $\alpha$ holoenzyme complex [42] and thus, their accessibility for the antibodies is relatively low. However, the activated holoenzymes can release the Camk $2 \alpha$ dimers to transactivate other holoenzymes [43] and in such case, the region 461-478 is exposed to the antibodies. Since the iFbp inhibits/tetramerizes $\mathrm{Fbp} 2$ in its T-state which cannot interact and activate Camk2 thus, it may be hypothesized that in such conditions we observed an increase in the amount of Camk $2 \alpha$ dodecamer, whose residues 461-478 are unavailable for the antibodies. As a result, an apparent decrease in Camk $2 \alpha$ amount was observed using the immunofluorescent technique but not the WB. On the other hand, activation of Camk $2 \alpha$ by the $\mathrm{Co}^{2+}$-saturated $\mathrm{Fbp} 2$ (also in the presence of iFbp) stimulated the motility of Camk $2 \alpha$ active subunits what resulted in the increase of $461-478$ residues availability to the antibodies. In both cases mentioned above, the changes in total Camk $2 \alpha$ could not be observed when monitored using WB. 

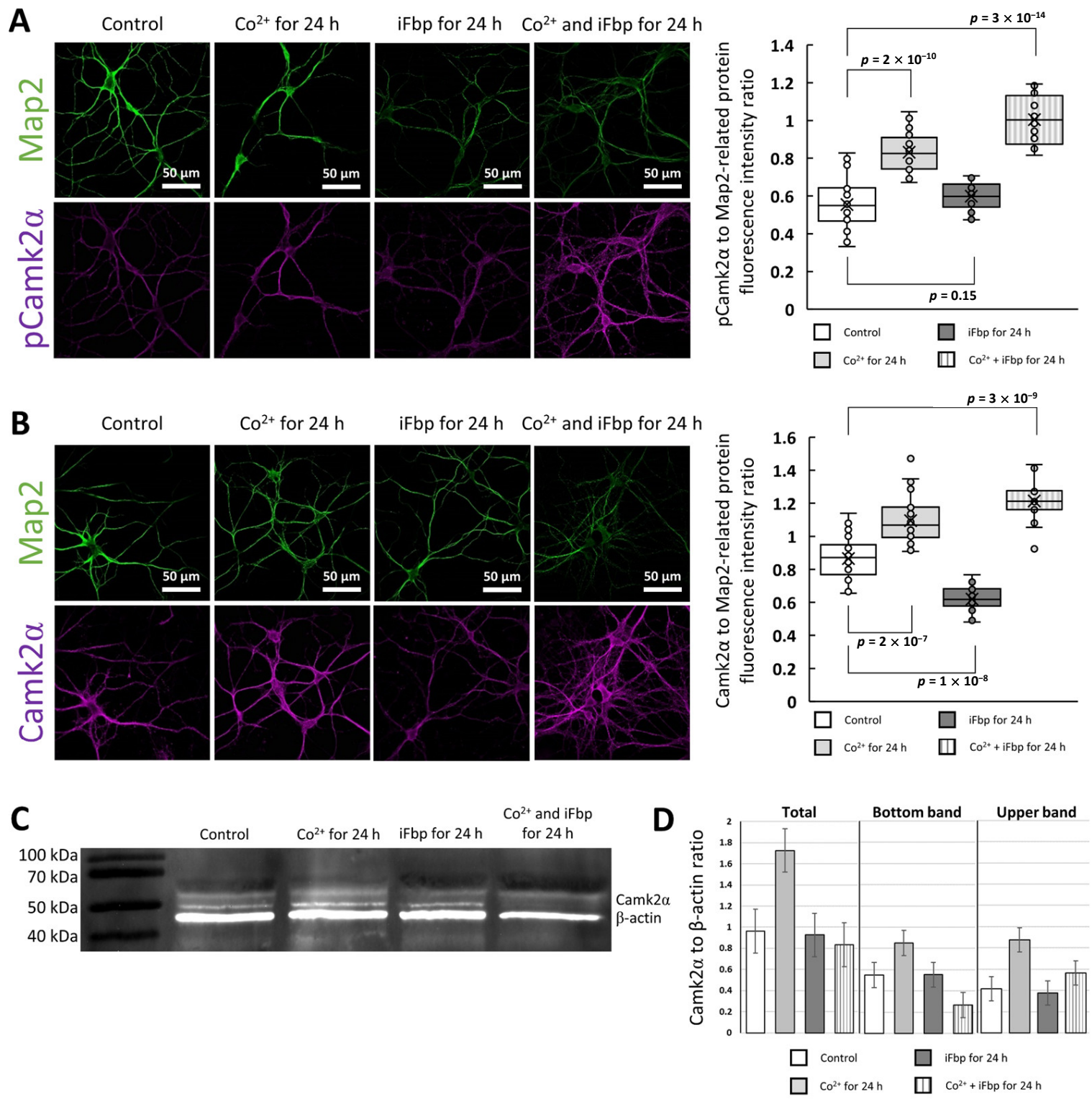

Figure 5. The effect of $\mathrm{Co}^{2+}$ on the amount of total and phosphorylated Camk2 $\alpha$ in neurons. The fluorescence related to total Camk $2 \alpha(\mathbf{A})$ and pThr286 Camk2 $\alpha(\mathbf{B})$ is significantly elevated in neurons incubated with $\mathrm{Co}^{2+}$ and $\mathrm{Co}^{2+} / \mathrm{iFbp}$, whereas in the cells treated with iFbp alone, the signal related to total Camk $2 \alpha$ decreases and pThr286 Camk $2 \alpha$-related fluorescence is unaltered. (C) Western blot and its densitometric analysis (D) reveals that the total amount of the kinase is increased only in $\mathrm{Co}^{2+}$-treated neurons, whereas the level of pThr286 Camk2 $\alpha$ is higher in $\mathrm{Co}^{2+}$ - and $\mathrm{Co}^{2+} / \mathrm{iFbp}$-incubated neurons.

In the previous study, we have demonstrated that the LTP induction correlates with the association of Fbp2 with mitochondria and Camk2 $\alpha$, and activation of the kinase activity [2]. Here, using the DuoLink technique we investigated if the $\mathrm{Co}^{2+}$-induced Fbp2 mitochondrial localization and increased Camk $2 \alpha$ phosphorylation are accompanied by Fbp2-Camk2 $\alpha$ complexes formation. Obtained results revealed that the intensity of Fbp2-Camk2 $\alpha$ complex-related fluorescence was significantly higher in neurons treated with $\mathrm{Co}^{2+}$, and with $\mathrm{Co}^{2+}$ and iFbp together than in untreated cells, whereas Fbp2 tetramerization with iFbp decreased the fluorescence associated with the complex formation (Figure 6a,b).

Since Fbp2-Camk $2 \alpha$ complex formation and Fbp2 association with mitochondria was apparently simultaneous we probed if the complex formation may be associated with the organelles. We found that the complex-related fluorescence strictly colocalized with the signal associated with mitochondria: the $\mathrm{M}$ value was between 0.7 and 0.8 (Figure $6 \mathrm{c}$ ). 

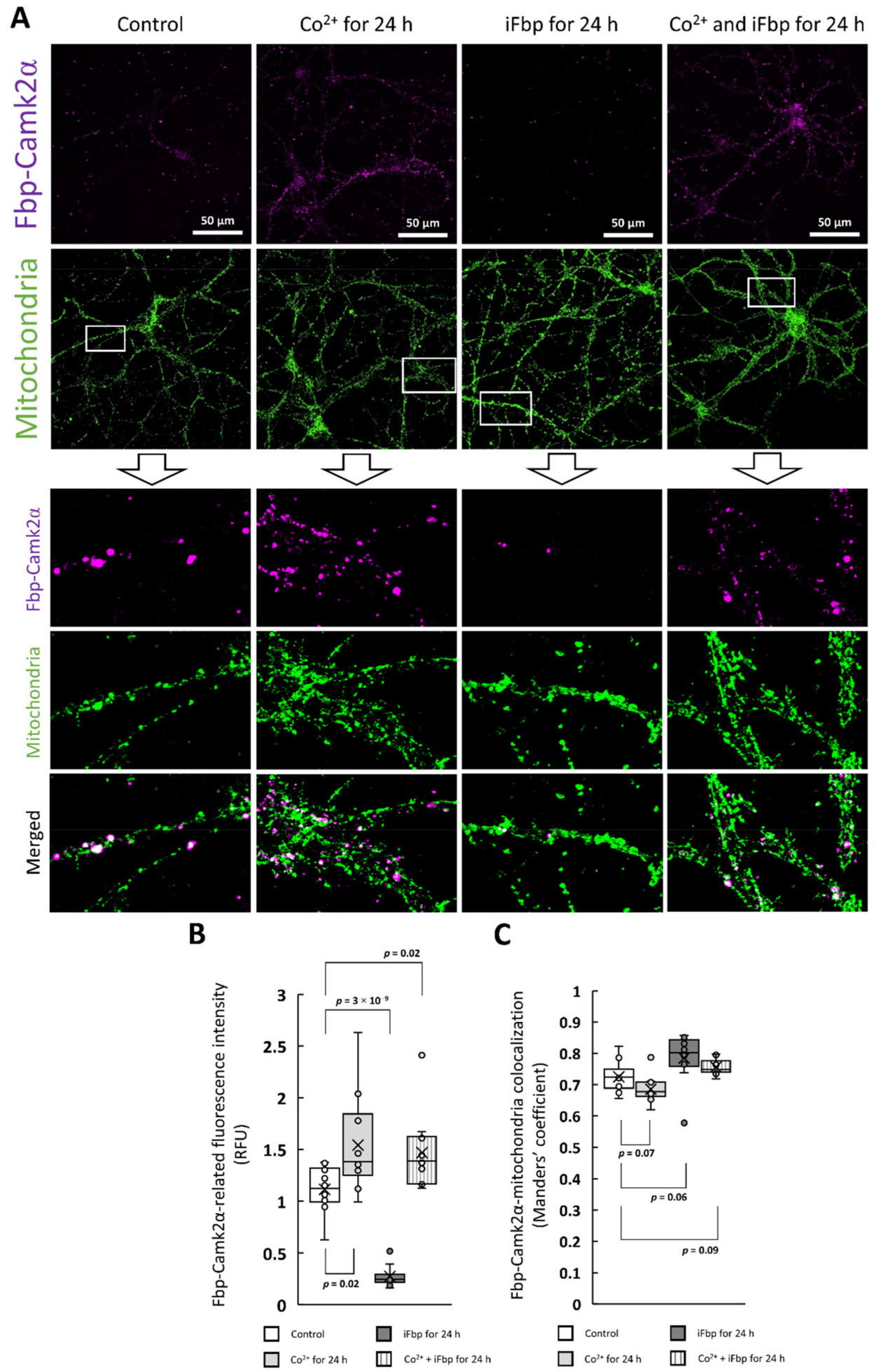

Figure 6. The Fbp-Camk2 $\alpha$ complex formation occurs on mitochondria. (A,B) The effect of $\mathrm{Co}^{2+}$ and iFbp on Fbp2-Camk2 $\alpha$ complex formation in the context of mitochondrial localization. $\mathrm{Co}^{2+}$ significantly increased the complex-related signal while iFbp decreases it. (C) The complex is almost exclusively localized to mitochondria.

The finding that the Camk2 $\alpha$ forms the complex with mitochondria-bound Fbp2 indicates that an appropriate quaternary structure of $\mathrm{Fbp} 2$ is required to associate with Camk2 $\alpha$. In other words, only the active/partially active Fbp2 (the dimeric, R-state tetrameric, and, as we show in this report, T-like active tetrameric enzyme) may interact with mitochondria and hence, may form the complex with Camk $2 \alpha$. 
To test if the $\mathrm{Co}^{2+}$-driven changes require long-term incubation with the cation $(24 \mathrm{~h})$ or may be observed also in a short-time window after $\mathrm{Co}^{2+}$ treatment we checked the Fbp2 localization in neurons after $1 \mathrm{~h}$ of the exposure. We found that the Fbp2-mitochondria colocalization coefficient increased significantly (from about 0.5 in the control neurons to 0.7 after the incubation) (Figure $7 \mathrm{a}$ ) and the amount of the phosphorylated Camk $2 \alpha$ (pThr286) was significantly elevated (Figure $7 \mathrm{~b}$ ).

A

A Contro $\mathrm{Co}^{2+}$ for $1 \mathrm{~h}$
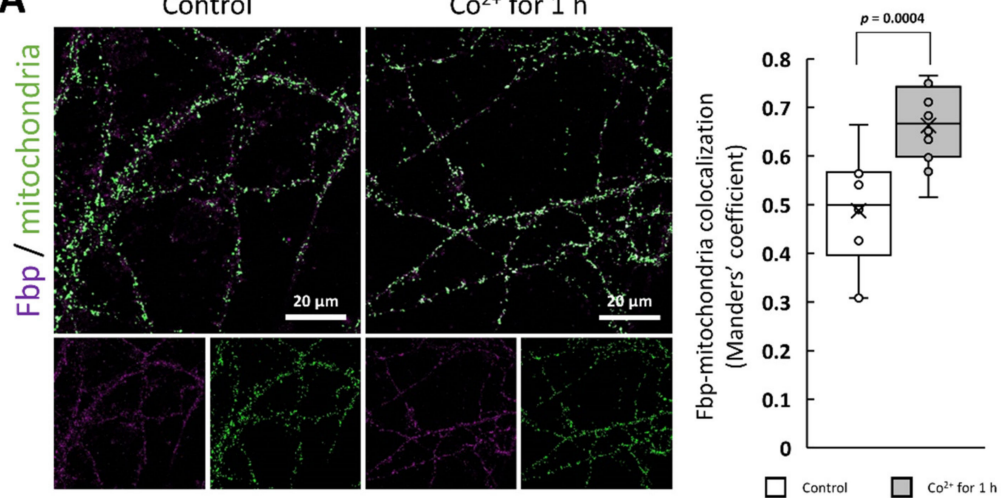

B

$\mathrm{Co}^{2+}$ for $1 \mathrm{~h}$
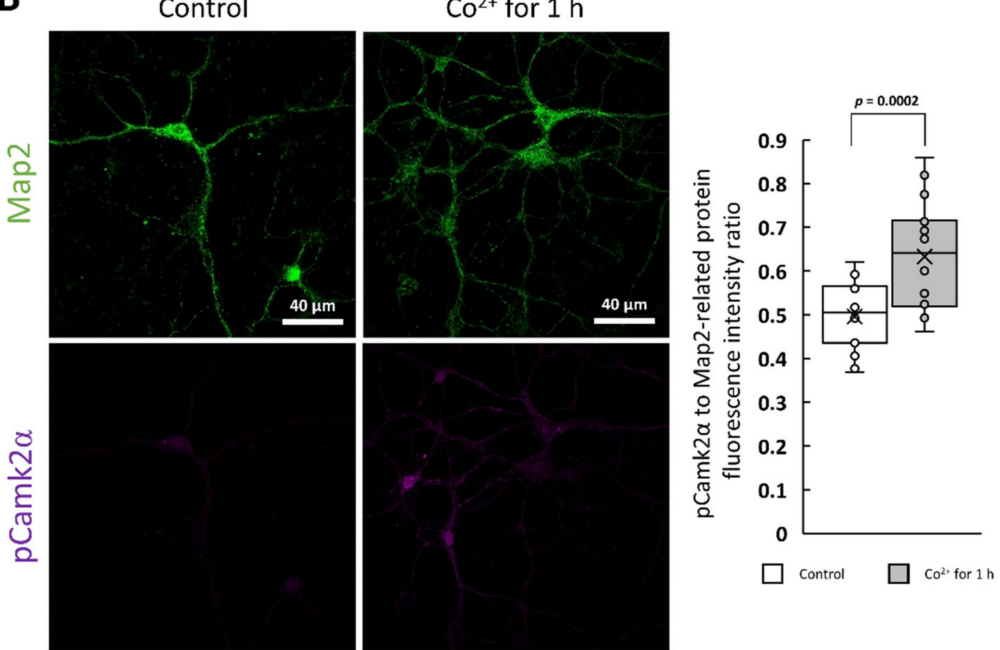

C

shRNA Non Target shRNA Non Target Control $\mathrm{Co}^{2+}$ for $1 \mathrm{~h}$

ShRNA anti-Fbp2

ShRNA anti-Fbp2
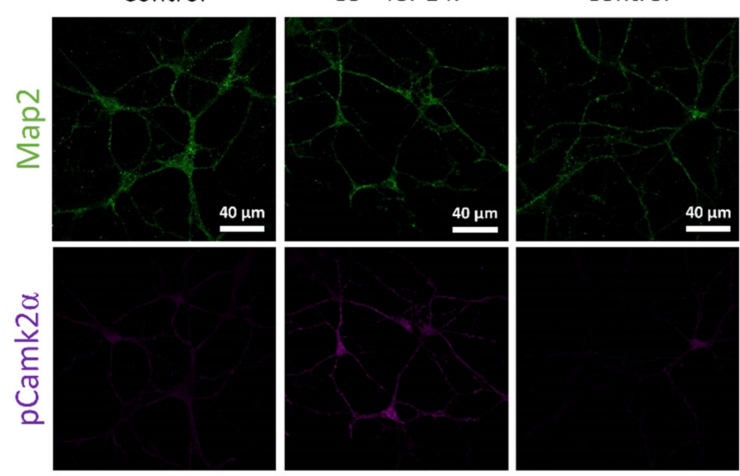
$\mathrm{Co}^{2+}$ for $1 \mathrm{~h}$

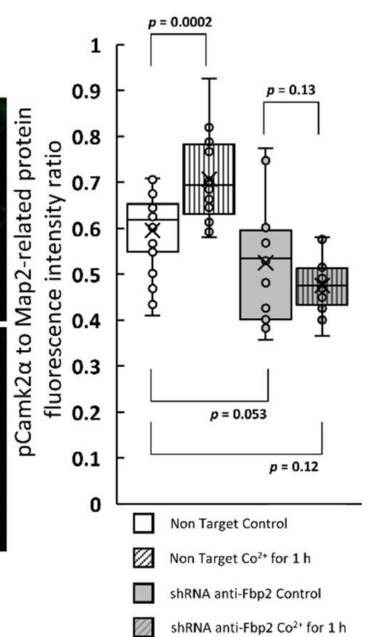

Figure 7. The effect of short-term $\mathrm{Co}^{2+}$-treatment of neurons. Incubation of neurons with $\mathrm{Co}^{2+}$ for $1 \mathrm{~h}$ resulted in $(\mathbf{A})$ the increased Fbp-mitochondria colocalization and (B) elevated amount of detected pThr286 Camk $2 \alpha$. (C) The increased pThr286 Camk2 $\alpha$ level after acute $\mathrm{Co}^{2+}$ treatment is not observed in neurons with partially silenced Fbp2 expression. 
Finally, to confirm that the increase in the Camk $2 \alpha$ autophosphorylation was related to the $\mathrm{Co}^{2+}$-driven $\mathrm{Fbp} 2$ action we used neurons with partially silenced $\mathrm{Fbp} 2$ expression and we observed that the phosphorylation of Camk2 $\alpha$ was practically unchanged after $1 \mathrm{~h}$ incubation with $\mathrm{CoCl}_{2}$ (Figure $7 \mathrm{c}$ ). This suggests that, at least in the short-term, $\mathrm{Co}^{2+}$ affects neuronal biology (that is, the function of active Camk2 $\alpha$ ) by modification of the Fbp2 structure.

\section{Materials and Methods}

\subsection{Protein Expression and Purification}

The wild-type human Fbp2 and its dimeric mutein L190G were expressed and purified as described in [8] with minor modifications: the dialysis was performed in $50 \mathrm{mM}$ Tris$\mathrm{HCl}$ buffer ( $\mathrm{pH} 7.4$ ) and $0.5 \mathrm{mM}$ EDTA, the protein solution was incubated with cellulose phosphate (Merck KGaA, c2258, Darmstadt, Germany) overnight at pH 7.0, the column bed was washed with $50 \mathrm{mM}$ Tris- $\mathrm{HCl}$ buffer $(\mathrm{pH} 7.4)$ and $0.5 \mathrm{mM}$ EDTA, and the protein was eluted with $100 \mathrm{mM}$ phosphate buffer (pH 8.0). SDS-PAGE electrophoresis was performed to verify the purity of Fbp2 and the gel was stained by the PAGE-Blue Protein Staining Solution (ThermoFisher, 24620, Waltham, MA, USA).

\subsection{Size-Exclusion Chromatography (SEC)}

The chromatographic analysis was employed to check oligomeric states of wild-type human Fbp2 and L190G mutein purified as described above. SEC was performed using the HiLoad ${ }^{\circledR} 16 / 600$ Superdex ${ }^{\circledR} 200$ pg (GE Healthcare, Chicago, IL, USA) column. The buffer used for separation of the oligomeric forms consisted of $50 \mathrm{mM}$ HEPES-NaOH ( $\mathrm{pH}$ 7.5), $150 \mathrm{mM} \mathrm{KCl}, 1 \mathrm{mM} \mathrm{MgCl}$. To check the effect of AMP and $\mathrm{Co}^{2+}$ the buffer was supplemented with $100 \mu \mathrm{M} \mathrm{CoCl}_{2}$ and/or $10 \mu \mathrm{M}$ AMP. The column was loaded with $0.5 \mathrm{mg}$ of one of the proteins and the separation was performed for $85 \mathrm{~min}$ with a flow of 1 $\mathrm{mL} / \mathrm{min}$. Samples were collected from the 55th minute with a frequency of 1 sample per $30 \mathrm{~s}$. Fbp2 concentration was determined spectrophotometrically assuming that at $280 \mathrm{~nm}$ $A_{1}^{1 \%} \mathrm{~cm}=6.3$.

\subsection{Native-PAGE}

The conformations of the purified wild-type human Fbp2 and L190G mutein were determined using the Native 9\% PAGE. Running buffers and gels contained: $200 \mathrm{mM}$ Glycine- $\mathrm{NaOH}$ ( $\mathrm{pH} 9.0$ ) and $1 \mathrm{mM} \mathrm{MgCl} 2$ and in some experiments, additional compounds (100 $\mu \mathrm{M} \mathrm{CoCl}_{2}$ and/or $10 \mu \mathrm{M}$ AMP). The electrophoretic separation was performed for $3 \mathrm{~h}$ at a constant voltage of $254 \mathrm{~V}$.

\subsection{Enzymatic Activity Assay}

All kinetic experiments were performed at $\mathrm{pH} 7.5,37^{\circ} \mathrm{C}$ using the glucose-6-phosphate isomerase-glucose-6-phosphate dehydrogenase coupled spectrophotometric assay [44]. The reaction mixture contained: $50 \mathrm{mM}$ HEPES-NaOH, $150 \mathrm{mM} \mathrm{KCl}, 10 \mathrm{U} / \mathrm{mL}$ glucose 6-phosphate dehydrogenase, $10 \mathrm{U} / \mathrm{mL}$ glucose 6-phosphate isomerase, $60 \mu \mathrm{M}$ fructose1,6-bisphosphate, $0.2 \mathrm{mM} \mathrm{NADP}{ }^{+}, 1 \mu \mathrm{g}$ of $\mathrm{Fbp} 2$ and variable concentrations of $\mathrm{MgCl}_{2}$ and $\mathrm{CoCl}_{2}$ in the total volume of $1 \mathrm{~mL}$. One unit (U) of enzyme activity is defined as the amount of the enzyme that catalyzes the formation of $1 \mu \mathrm{mol}$ of product per minute. The kinetic parameters were estimated using GraFit Version 4 software (Erithacus Software Limited, Surrey, UK). The data on the effect of $\mathrm{Co}^{2+}$ were fitted to the following equation:

$$
\frac{a}{A_{\max }}=\frac{\left[\mathrm{Co}^{2+}\right]^{n}}{\left[\mathrm{Co}_{0.5}^{2+}\right]^{n}+\left[\mathrm{Co}^{2+}\right]^{n}}
$$

where $a$ is the observed activity (expressed in $\mathrm{U} / \mathrm{mg}$ ) at a specific concentration of $\mathrm{Co}^{2+}$, $A_{\text {max }}$ is the activity in the absence of $\mathrm{Co}^{2+},\left[\mathrm{Co}^{2+}\right]$ is the concentration of the cation, and $\left[\mathrm{Co}_{0.5}^{2+}\right]$ is the concentration of $\mathrm{Co}^{2+}$ that causes $50 \%$ changes in the maximal activity. The 
positive cooperativity is observed at $n$ (Hill coefficient) $>1$, whereas cooperativity is absent when $n=1$.

\subsection{Cell Culture, LTP Induction, and Fbp2 Expression Silencing}

Hippocampal neurons were isolated from 0-2-day-old newborn C57BL6 mice and cultured as described previously [45]. The culture medium contained $2.5 \mathrm{mM}$ glucose. The cells were planted at a density of 25,000 cells $/ \mathrm{cm}^{2}$. All the experiments were performed using neuronal cultures on the 14 th day of in vitro (DIV).

LTP was induced according to the protocol described previously $[46,47]$. Prior to the LTP induction, the cultures were transferred to the Ringer's solution $\left(37^{\circ} \mathrm{C}\right)$.

Fbp2 expression silencing was performed as described in [2]. Briefly, for the silencing of the shRNA against 3'UTR of Fbp2 mRNA (FBP2 MISSION ${ }^{\text {TM }}$ shRNA Lentiviral Transduction Particles; Merck KGaA, Darmstadt, Germany, SHCLNV-NM_007994) was used. The shRNA sequence was 5'-CCGGAGATGA ATGAGCTATG GAGATCTCGA GATCTCCATA GCTCATTCAT CTTTTTTG-3', and the transduction particles were added to the cultures at $14 \mathrm{DIV}$ in the amount of $2.5 \times 10^{5}$. The transduction lasted for $72 \mathrm{~h}$. In controls, neurons were treated with the non-target shRNA (MISSION ${ }^{\mathrm{TM}}$ TRC2 Plko.5 Non-Target shRNA Control Plasmid DNA, Merck KGaA, Darmstadt, Germany) at the concentration of $5 \mathrm{ng} / \mathrm{mL}$.

\subsection{Chemicals}

$\mathrm{CoCl}_{2}$ was added to the cultures at a final concentration of $100 \mu \mathrm{M}$ at $14 \mathrm{DIV}$ for 1 or $24 \mathrm{~h}$. For pharmacological inhibition of Fbp2 the enzyme inhibitor 2,5-dichloro-N-(5-chloro2-benzoxazolyl)-benzenesulfonamide (Cayman Chemicals, Ann Arbor, MI, USA, 18860), further called iFbp, was added to the cultures at a final concentration of $5 \mu \mathrm{M}$ for $24 \mathrm{~h}$.

\subsection{Immunofluorescence}

The immunofluorescence studies were performed as described previously [48]. The cells were incubated overnight at $4{ }^{\circ} \mathrm{C}$ with respective primary antibodies: rabbit anti-Fbp (1:1000, isolated and purified as described in [49]), rabbit anti-Camk2 $\alpha$ (1:1000, Merck KGaA, Darmstadt, Germany, C6974), mouse anti-Camk2 $\alpha$ pT286 (1:1000, Abcam, Cambridge, UK, ab171095), rabbit anti-Map2 (1:1000, Merck KGaA, Darmstadt, Germany, M3696) and mouse anti-Map2 (1:1000, Merck KGaA, Darmstadt, Germany, M4403). For the colocalization studies, the following primary antibodies were used: mouse anti-Fbp2 (1:1000, Santa Cruz Biotechnology, Dallas, TX, USA, sc-271799), rabbit anti-Tomm20 (Merck KGaA, Darmstadt, Germany, HPA011562). The primary antibodies were detected using fluorophore-labeled secondary antibodies: goat anti-mouse-AlexaFluor488 (1:2000, Abcam, Cambridge, UK, ab150113), goat anti-mouse-AlexaFluor633 (1:2000, ThermoFisher Scientific, Waltham, MA, USA, a21050), goat anti-rabbit-AlexaFluor488 (1:2000, ThermoFisher Scientific, Waltham, MA, USA, a11034) or goat anti-rabbit-AlexaFluor633 (1:2000, ThermoFisher Scientific, Waltham, MA, USA, a21070). In controls, the primary antibodies were omitted. Nuclei were counterstained with DAPI. To visualize mitochondria in situ detection of protein interaction, the cultures were incubated with $0.1 \mu \mathrm{M}$ MitoTracker ${ }^{\mathrm{TM}}$ Deep Red FM (ThermoFisher Scientific, Waltham, MA, USA, M22426) for $30 \mathrm{~min}$ at $37^{\circ} \mathrm{C}$.

\subsection{In Situ Detection of Proteins Interaction}

Detection and visualization of Fbp-Camk2 $\alpha$ interaction was performed using the DuoLink ${ }^{\circledR}$ In Situ Orange Starter Kit Mouse/Rabbit (Merck KGaA, Darmstadt, Germany) according to the manufacturer's instruction, using mouse anti-Fbp2 (1:1000, Santa Cruz Biotechnology, Dallas, TX, USA, sc-271799) and rabbit anti-Camk2 $\alpha$ (1:1000, Merck KGaA, Darmstadt, Germany, C6974) primary antibodies. In controls, the primary antibodies were omitted. 


\subsection{Western Blot}

Western blot of neuronal protein extracts was performed as described previously [48]. The following primary antibodies were used: rabbit anti-Fbp (1:500, isolated and purified as described in [49]), rabbit anti-Camk2 $\alpha$ (1:1000, Merck KGaA, Darmstadt, Germany, C6974) and mouse anti- $\beta$-actin (1:50,000, Merck KGaA, Darmstadt, Germany, A1978). The following secondary antibodies were used: goat anti-rabbit peroxidase-conjugated (1:50,000, Merck KGaA, Darmstadt, Germany, a0545) and goat anti-mouse peroxidaseconjugated antibodies (1:100,000, Merck KGaA, Darmstadt, Germany, a9044) were used. The reaction was visualized chemiluminescently.

\subsection{Confocal Microscopy and Fluorescence Analysis}

Confocal microscopy analysis was performed as described previously [48]. The fluorescence quantification was carried out using the ImageJ software [50]. The mean fluorescence intensity was measured from regions of interest defined based on the Map2 immunostaining, and the results are presented as the ratio of the protein of interest- to Map2-related fluorescence intensity. The images were taken from randomly selected areas and at least 30 images were taken for an analyzed condition.

For the colocalization analysis, the Manders' coefficient (M) was used. The coefficient was determined as the ratio of summed intensities of pixels from the protein of interest image for which the mitochondrial channel intensity was above zero to the total intensity in the protein of interest channel [51,52].

\subsection{Statistical Analysis}

Data were checked for normality using the Shapiro-Wilk test, and for equality of variances using the F-test. To verify the significance of observed differences the Students' $t$-test was used for groups with normal distribution, and the Mann-Whitney's U-test for results deviating from a normal distribution. A probability of $p<0.05$ was considered to be a significant difference. Results are expressed as a mean and standard deviation, and the data are visualized with box plots wherein center lines show the medians, and $x$ marks show means. The bottom box limit indicates the 1st quartile, and the upper box limit indicates the 3rd quartile. Whiskers range between two extreme data points within the group. Outliers are placed beyond the whiskers. Data were analyzes using SigmaPlot11 (Systat Software, San Jose, CA, USA) and Microsoft Excel 2016 software (Redmond, WA, USA). All the experiments were done at least in triplicate.

\section{Conclusions}

In this study, we presented a line of evidence that $\mathrm{Co}^{2+}$ stimulates the activity of Camk $2 \alpha$ by altering the quaternary structure of $\mathrm{Fbp} 2$ and its affinity to mitochondria.

In the presence of allosteric inhibitors ( $\left.\mathrm{AMP}, \mathrm{NAD}^{+}, \mathrm{iFbp}\right), \mathrm{Fbp} 2$ adopts the inactive T-state which cannot interact with mitochondria. However, in the presence of $\mathrm{Co}^{2+}, \mathrm{Fbp} 2$ adopts the new, T-like conformation which is active even in the presence of the allosteric inhibitors, and which is evidently different from the canonical T-state. Importantly, in the T-like conformation, $\mathrm{Fbp} 2$ can interact with mitochondria as effectively as in its active states: the dimer and R-state. The interaction of $\mathrm{Co}^{2+}$-saturated $\mathrm{Fbp} 2$ with mitochondria results in the autoactivation of Camk $2 \alpha$.

Recently, we have demonstrated that Fbp2 interacts with mitochondria and Camk $2 \alpha$ in the LTP-dependent manner. We have hypothesized that in physiological conditions, a decrease in $\mathrm{NAD}^{+}$(an allosteric inhibitor of $\mathrm{Fbp} 2$ ) concentration may be a signal stimulating these interactions as $\mathrm{NAD}^{+}$reduction decreases the pool of Fbp2 in the canonical T-state and thus, augments the number of Fbp molecules interacting with binding partners [2]. Here, we demonstrated that $\mathrm{Co}^{2+}$, and probably any factor that can block the transition of Fbp2 to the canonical T-state is sufficient for stimulation of the enzyme association with mitochondria and Camk $2 \alpha$ what leads to autoactivation of the kinase. 
This may reflect the toxic effect of $\mathrm{Co}^{2+}$ on brain function and explain the mechanism of epileptogenic activity of the cation since the active Camk $2 \alpha$ facilitates neuronal membrane depolarization elevating the amount of synaptic AMPAR and thus, increasing $\mathrm{Na}^{+}$conductance.

Author Contributions: P.D.-conceptualization, methodology, validation, formal analysis, investigation, data curation, writing — original draft preparation, visualization; B.B. - methodology, formal analysis, investigation, data curation, writing - original draft preparation; D.R.-formal analysis, writing - review and editing, supervision. All authors have read and agreed to the published version of the manuscript.

Funding: This research was funded by the Polish National Science Centre: UMO-2015/19/B/NZ1/00332.

Institutional Review Board Statement: Not applicable.

Informed Consent Statement: Not applicable.

Data Availability Statement: The data presented in this study are available on request from the corresponding authors.

Conflicts of Interest: The authors declare no conflict of interest.

\section{References}

1. Gizak, A.; Duda, P.; Wisniewski, J.; Rakus, D. Fructose-1,6-bisphosphatase: From a glucose metabolism enzyme to multifaceted regulator of a cell fate. Adv. Biol. Regul. 2019, 72, 41-50. [CrossRef] [PubMed]

2. Duda, P.; Wójtowicz, T.; Janczara, J.; Krowarsch, D.; Czyrek, A.; Gizak, A.; Rakus, D. Fructose 1,6-Bisphosphatase 2 Plays a Crucial Role in the Induction and Maintenance of Long-Term Potentiation. Cells 2020, 9, 1375. [CrossRef] [PubMed]

3. Huangyang, P.; Li, F.; Lee, P.; Nissim, I.; Weljie, A.M.; Mancuso, A.; Li, B.; Keith, B.; Yoon, S.S.; Celeste Simon, M. Fructose-1,6Bisphosphatase 2 Inhibits Sarcoma Progression by Restraining Mitochondrial Biogenesis. Cell Metab. 2020, 31, 174-188. [CrossRef] [PubMed]

4. Duda, P.; Janczara, J.; McCubrey, J.A.; Gizak, A.; Rakus, D. The Reverse Warburg Effect is Associated with Fbp2-Dependent Hif1 $\alpha$ Regulation in Cancer Cells Stimulated by Fibroblasts. Cells 2020, 14, 205. [CrossRef] [PubMed]

5. Li, B.; Qiu, B.; Lee, D.S.M.; Walton, Z.E.; Ochocki, J.D.; Mathew, L.K.; Mancuso, A.; Gade, T.P.F.; Keith, B.; Nissim, I.; et al. Fructose-1,6-bisphosphatase opposes renal carcinoma progression. Nature 2014, 513, 251-255. [CrossRef]

6. Hajka, D.; Duda, P.; Wójcicka, O.; Drulis-Fajdasz, D.; Rakus, D.; Gizak, A. Expression of FBP2, a newly discovered constituent of memory formation mechanisms, is regulated by astrocyte-neuron crosstalk. Int. J. Mol. Sci. 2020, 21, 6903. [CrossRef]

7. Gizak, A.; Pirog, M.; Rakus, D. Muscle FBPase binds to cardiomyocyte mitochondria under glycogen synthase kinase-3 inhibition or elevation of cellular $\mathrm{Ca}^{2+}$ level. FEBS Lett. 2012, 586, 13-19. [CrossRef]

8. Wiśniewski, J.; Piróg, M.; Hołubowicz, R.; Dobryszycki, P.; McCubrey, J.A.; Rakus, D.; Gizak, A. Dimeric and tetrameric forms of muscle fructose-1,6-bisphosphatase play different roles in the cell. Oncotarget 2017, 8, 115420-115433. [CrossRef] [PubMed]

9. Barciszewski, J.; Wisniewski, J.; Kolodziejczyk, R.; Jaskolski, M.; Rakus, D.; Dzugaj, A. T-to-R switch of muscle fructose-1,6bisphosphatase involves fundamental changes of secondary and quaternary structure. Acta. Crystallogr. Sect. D Struct. Biol. 2016, 72, 536-550. [CrossRef]

10. Rakus, D.; Tillmann, H.; Wysocki, R.; Ulaszewski, S.; Eschrich, K.; Dzugaj, A. Different sensitivities of mutants and chimeric forms of human muscle and liver fructose-1,6-bisphosphatases towards AMP. Biological. Chem. 2003, 384, 51-58. [CrossRef]

11. Pirog, M.; Gizak, A.; Rakus, D. Changes in quaternary structure of muscle fructose-1,6-bisphosphatase regulate affinity of the enzyme to mitochondria. Int. J. Biochem. Cell Biol. 2014, 48, 55-59. [CrossRef] [PubMed]

12. Gizak, A.; Zarzycki, M.; Rakus, D. Nuclear targeting of FBPase in HL-1 cells is controlled by beta-1 adrenergic receptor-activated Gs protein signaling cascade. Biochim. Biophys. Acta Mol. Cell Res. 2009, 1793, 871-877. [CrossRef]

13. Gizak, A.; Majkowski, M.; Dus, D.; Dzugaj, A. Calcium inhibits muscle FBPase and affects its intracellular localization in cardiomyocytes. FEBS Lett. 2004, 576, 445-448. [CrossRef]

14. Tejwani, G.A.; Pedrosa, F.O.; Pontremoli, S.; Horecker, B.L. Dual role of Zn2+ as inhibitor and activator of fructose 1,6 bisphosphatase of rat liver. Proc. Natl. Acad. Sci. USA 1976, 73, 2692-2695. [CrossRef] [PubMed]

15. Takahashi-Iñiguez, T.; García-Hernandez, E.; Arreguín-Espinosa, R.; Flores, M.E. Role of Vitamin B12 on methylmalonyl-CoA mutase activity. J. Zhejiang Univ. Sci. B 2012, 13, 423-437. [CrossRef] [PubMed]

16. Froese, D.S.; Fowler, B.; Baumgartner, M.R. Vitamin B12, folate, and the methionine remethylation cycle-Biochemistry, pathways, and regulation. J. Inherit. Metab. Dis. 2019, 42, 673-685. [CrossRef] [PubMed]

17. Calderón-Ospina, C.A.; Nava-Mesa, M.O. B Vitamins in the nervous system: Current knowledge of the biochemical modes of action and synergies of thiamine, pyridoxine, and cobalamin. CNS Neurosci. Ther. 2020, 26, 5-13. [CrossRef]

18. Catalani, S.; Rizzetti, M.C.; Padovani, A.; Apostoli, P. Neurotoxicity of cobalt. Hum. Exp. Toxicol. 2012, 31, 421-437. [CrossRef] [PubMed] 
19. Ensinger, H.A.; Pauly, H.E.; Pfleiderer, G.; Stiefel, T. The role of Zn(II) in calf intestinal alkaline phosphatase studied by the influence of chelating agents and chemical modification of histidine residues. Biochim. Biophys. Acta. 1978, 527, 432-441. [CrossRef]

20. Mao, X.; Wong, A.A.; Crawford, R.W. Cobalt toxicity-An emerging clinical problem in patients with metal-on-metal hip prostheses? Med. J. Aust. 2011, 20, 649-651. [CrossRef]

21. Schirrmacher, U.O.E. Case of Cobalt Poisoning. Br. Med. J. 1967, 1, 544-545. [CrossRef] [PubMed]

22. Licht, A.; Oliver, M.; Rachmilewitz, E.A. Optic atrophy following treatment with cobalt chloride in a patient with pancytopenia and hypercellular marrow. Isr. J. Med. Sci. 1972, 8, 61-66.

23. Dow, R.S.; Fernández-Guardiola, A.; Manni, E. The production of cobalt experimental epilepsy in the rat. Electroencephalogr. Clin. Neurophysiol. 1962, 14, 399-407. [CrossRef]

24. Mutani, R. Cobalt Experimental Hippocampal Epilepsy in the Cat. Epilepsia 1967, 8, 223-240. [CrossRef] [PubMed]

25. Grimm, R.J.; Frazee, J.G.; Kawasaki, T.; Savić, M. Cobalt epilepsy in the squirrel monkey. Electroencephalogr. Clin. Neurophysiol. 1970, 29, 525-528. [CrossRef]

26. Chang, J.H.; Yang, X.F.; Zempel, J.M.; Rothman, S.M. The unilateral cobalt wire model of neocortical epilepsy: A method of producing subacute focal seizures in rodents. Epilepsy Res. 2004, 61, 153-160. [CrossRef] [PubMed]

27. Craig, C.R.; Colasanti, B.K. GABA receptors, lipids, and gangliosides in cobalt epileptic focus. Adv. Neurol. 1986, 44, 379-391. [PubMed]

28. He, J.; Hsiang, H.L.; Wu, C.; Mylvagnanam, S.; Carlen, P.L.; Zhang, L. Cellular mechanisms of cobalt-induced hippocampal epileptiform discharges. Epilepsia 2009, 50, 99-115. [CrossRef] [PubMed]

29. Lai, C.; Gum, R.J.; Daly, M.; Fry, E.H.; Hutchins, C.; Abad-Zapatero, C.; von Geldern, T.W. Benzoxazole benzenesulfonamides as allosteric inhibitors of fructose-1,6-bisphosphatase. Bioorg. Med. Chem. Lett. 2006, 16, 1807-1810. [CrossRef]

30. Von Geldern, T.W.; Lai, C.; Gum, R.J.; Daly, M.; Sun, C.; Fry, E.H.; Abad-Zapatero, C. Benzoxazole benzenesulfonamides are novel allosteric inhibitors of fructose-1,6-bisphosphatase with a distinct binding mode. Bioorg. Med. Chem. Lett. 2006, 16, 1811-1815. [CrossRef]

31. Pedrosa, F.O.; Pontremoli, S.; Horecker, B.L. Binding of Zn2+ to rat liver fructose-1,6-bisphosphatase and its effect on the catalytic properties. Proc. Natl. Acad. Sci. USA 1977, 74, 2742-2745. [CrossRef] [PubMed]

32. Choe, J.Y.; Fromm, H.J.; Honzatko, R.B. Crystal structures of fructose 1,6-bisphosphatase: Mechanism of catalysis and allosteric inhibition revealed in product complexes. Biochemistry 2000, 39, 8565-8574. [CrossRef] [PubMed]

33. Tejwani, G.A. Regulation of fructose-bisphosphatase activity. Adv. Enzymol. Relat. Areas Mol Biol. 1983, 54, 121-194. [CrossRef]

34. Rulisek, L.; Vondrasek, J. Coordination geometries of selected transition metal ion $\left(\mathrm{Co}^{2+}, \mathrm{Ni}^{2+}, \mathrm{Cu}^{2+}, \mathrm{Zn}^{2+}, \mathrm{Cd}^{2+}, \mathrm{and} \mathrm{Hg}^{2+}\right)$ in metalloproteins. J. Inorg. Biochem. 1998, 71, 115-127. [CrossRef]

35. Sellin, S.; Mannervik, B. Metal dissociation constants for glyoxalase I reconstituted with $\mathrm{Zn}^{2+}, \mathrm{Co}^{2+}, \mathrm{Mn}^{2+}$, and $\mathrm{Mg}^{2+}$. J. Biol. Chem. 1984, 259, 11426-11429. [CrossRef]

36. Schneider, G.; Zeppezauer, M. Kinetics and mechanisms of the recombination of $\mathrm{Zn}^{2+}, \mathrm{Co}^{2+}$, and $\mathrm{Ni}^{2+}$ with the metal-depleted catalytic site of horse liver alcohol dehydrogenase. J. Inorg. Bioch. 1983, 18, 59-69. [CrossRef]

37. Hanada, T. Ionotropic glutamate receptors in epilepsy: A review focusing on ampa and nmda receptors. Biomolecules 2020, 18, 464. [CrossRef] [PubMed]

38. Lua, W.; Isozaki, K.; Roche, K.W.; Nicoll, R.A. Synaptic targeting of AMPA receptors is regulated by a CaMKII site in the first intracellular loop of GluA1. Proc. Natl. Acad. Sci. USA 2010, 107, 22266-22271. [CrossRef]

39. Barria, A.; Muller, D.; Derkach, V.; Griffith, L.C.; Soderling, T.R. Regulatory phosphorylation of AMPA-type glutamate receptors by CaM-KII during long-term potentiation. Science 1997, 276, 2042-2045. [CrossRef] [PubMed]

40. Kristensen, A.S.; Jenkins, M.A.; Banke, T.G.; Schousboe, A.; Makino, Y.; Johnson, R.C.; Huganir, R.; Traynelis, S.F. Mechanism of Ca2+/calmodulin-dependent kinase II regulation of AMPA receptor gating. Nat. Neurosci. 2011, 14, 727-735. [CrossRef]

41. Carruthers, N.J.; Parker, G.C.; Gratsch, T.; Caruso, J.A.; Stemmer, P.M. Protein mobility shifts contribute to gel electrophoresis liquid chromatography analysis. J. Biomol. Tech. 2015, 26, 103-112. [CrossRef] [PubMed]

42. Myers, J.B.; Zaegel, V.; Coultrap, S.J.; Miller, A.P.; Bayer, K.U.; Reichow, S.L. The CaMKII holoenzyme structure in activationcompetent conformations. Nat. Commun. 2017, 8, 15742. [CrossRef]

43. Bhattacharyya, M.; Stratton, M.M.; Going, C.C.; McSpadden, E.D.; Huang, Y.; Susa, A.C.; Elleman, A.; Cao, Y.M.; Pappireddi, N.; Burkhardt, P.; et al. Molecular mechanism of activation-triggered subunit exchange in Ca2+/calmodulin-dependent protein kinase II. Elife 2016, 5, e13405. [CrossRef]

44. Skalecki, K.; Mularczyk, W.; Dzugaj, A. Kinetic properties of D-fructose-1,6-bisphosphate 1-phosphohydrolase isolated from human muscle. Biochem. J. 1995, 310, 1029-1035. [CrossRef] [PubMed]

45. Mozrzymas, J.; Szczęsny, T.; Rakus, D. The effect of glycogen phosphorolysis on basal glutaminergic transmission. Biochem. Biophys Res. Commun. 2011, 404, 652-655. [CrossRef] [PubMed]

46. Lu, W.; Man, H.; Ju, W.; Trimble, W.S.; MacDonald, J.F.; Wang, Y.T. Activation of synaptic NMDA receptors induces membrane insertion of new AMPA receptors and LTP in cultured hippocampal neurons. Neuron 2001, 29, 243-254. [CrossRef]

47. Chen, R.-Q.; Wang, S.-H.; Yao, W.; Wang, J.-J.; Ji, F.; Yan, J.-Z.; Ren, S.-Q.; Chen, Z.; Liu, S.-Y.; Lu, W. Role of glycine receptors in glycine-induced LTD in hippocampal CA1 pyramidal neurons. Neuropsychopharmacology 2011, 36, 1948-1958. [CrossRef] 
48. Mamczur, P.; Borsuk, B.; Paszko, J.; Sas, Z.; Mozrzymas, J.; Wiśniewski, J.R.; Gizak, A.; Rakus, D. Astrocyte-neuron crosstalk regulates the expression and subcellular localization of carbohydrate metabolism enzymes. Glia 2015, 63, 328-340. [CrossRef]

49. Gizak, A.; Dzugaj, A. FBPase is in the nuclei of cardiomyocytes. FEBS Lett. 2003, 539, 51-55. [CrossRef]

50. Schneider, C.A.; Rasband, W.S.; Eliceiri, K.W. NIH Image to ImageJ: 25 years of image analysis. Nat. Methods. 2012, 9, 671-675. [CrossRef] [PubMed]

51. Bolte, S.; Cordelières, F.P. A guided tour into subcellular colocalization analysis in light microscopy. J. Microsc. 2006, 224, 213-232. [CrossRef] [PubMed]

52. Dunn, K.W.; Kamocka, M.M.; McDonald, J.H. A practical guide to evaluating colocalization in biological microscopy. Am. J. Physiol. Cell Physiol. 2011, 300, C723-C742. [CrossRef] [PubMed] 